\title{
Street Children and its Impact on Educational Attainment in North-Western State (Punjab) of Pakistan
}

\author{
${ }^{1}$ Somaiyeh Vedadi, ${ }^{1}$ Baharuddin Bin Aris, ${ }^{1,2}$ Syed Muhammad Javed Iqbal, ${ }^{*}$ Saqib Muneer ${ }^{1}$ \\ ${ }^{1}$ Universiti Teknologi Malaysia, Malaysia \\ 2The Islamia University of Bahawalpur, Pakistan \\ *saqibmuneer85@gmail.com
}

\begin{abstract}
Street children constitute a violent category in most societies; they have considered what society considers appropriate relationships with major institutions of childhood such as family, education and health. The study sets to examine background characteristics of street children, surviving strategies of street children, abuse experienced by street children, problems encountered on the street. The sample of 250 respondents was selected by simple random sampling technique through well-structured questionnaire. The instrument comprised on two sections. According to the results of the study the neglect is most common abuse experienced by children in the selected area of study and it is increasing highly. In addition, it was discovered that socio-economic status serves as a predictor to existence of street children in country i.e. as the age increases, level of abuse also increases. Therefore, the study recommends that a better social supports for children, the need to establish street rehabilitation strategy to come-in to serve as a very effective way to support street children as it occurs at locations where they live.
\end{abstract}

Keywords: Street Children, educational attainment, Socio-Economic Status, Street Rehabilitation Strategy

\section{Introduction}

In a bid to embrace intellectual, physical, emotional and social changes which occur since the birth of all children geared towards fighting against the prevailing magnitude of street children as called for urgent attention. Though, people change the lives of children throughout childhood. While during this period, vulnerable newly born babies are transformed into capable young persons who are self-aware, have mastered language, can rationally think, possess a unique personality, and are socially connected. Hence the people learn since birth to death. Anyhow, perhaps the most vulnerable section of the people lives belong to street childhood, which undergoes from human deficiencies of all forms (Ekundayo, 2001). Especially in developing countries, many children have to earn forcefully to live due to their distressed and susceptible situation. Common problems in these children are run-away or abandoned children, these types of children are also majorly characterized with numerous disgusting health issues (Ekundayo, 2001). According to data on children, The United Nation reported that nearly 270 million street children exist in the world and these numbers are rising day by day. Disturbingly, 50\% of these children can't survive even more than first four years of their lives. Similarly, a child who survives up to 8 years of life has a $50 \%$ chance to live above age of 12 (United Nation Data, 2009).

Majority of these children are abandoned or abused by their own families. For instance, in Pakistan, it was published in the Jung Newspaper (2012) that 18\% of street girls reported to be the victims of incest. Other common reasons are extreme family poverty, parents' death, unbalanced situation of socio-economic conditions of the country, and domestic armed conflicts among the families that caused various families to leave their homes. The street children are compelled to be pickpockets, beggars, thieves, and even girls and women often adopt prostitution for the reason to survive. Many younger are involved in street crimes by being the parts of different gangs commit violence, and become drug addicts. They use different cheap drugs such as, inhaling paint thinners, glue, and other toxics while being unaware that it can destroy their brain cells and tissues of organs. Street educators in Pakistan, China, Mexico, Russia Burkina Faso and other countries continuously find various intoxicated young kids in the age of 12 , trying to escape the hunger, pain, and disparity of street life. However, according to United Nation Educational Policy, education is the basic human right of the children all around the world (United Nation, 1948). The United Nation has passed a rule 
that it the responsibility of the respective governments and parents to provide basic education to every child (UN, 2004; UNICEF, 2008). It is clear from the above discussion that formal education is the basic right of every street child which can't be denied.

The population of Pakistan is estimated to be over 185 million people of whom almost 40 percent are under the age of 15 years (CIA, 2009). In a country where there is political fluctuation, economic instability and the only form of stable growth is in terms of the population, poverty has become an inevitable problem. It is estimated that there are 130,000 street children in Punjab (Pakistan), surviving in the major cities and urban centres, making them one of the largest and most neglected social groups in the country (Asian Human Rights Commission, 2005). Therefore, the current study examines the prevalence of street children and its influence on academic attainment in some major cities of Pakistan, which includes Sialkot, Gujranwala, Gujrat, Wazirabad, Faisalabad and Bahawalpur.

\section{Overview of Prevalence of Street Children in Pakistan}

Street children phenomenon is a major human development problem that is been experiences all over the developing world. A major cause of this phenomenon in Pakistan is the lack of access to basic education and drop out in schools as a result of poverty and the harsh effect of the structural adjustment programme which exist to ameliorate poverty in country. And also bridging the existing gap in Pakistani access to infrastructural facilities through the unlimited provision of basic educational services for the less privileged in the country, also reducing the prevalence of children on street embracing superlative in educational programmes (Tufail, 2005; Ali et al., 2004). The phenomenon of street children has become prominent globally with serious implications for the survival of these children. The presence of streets children in major cities of the world has transcended the level where it was viewed as strictly uncommon occurrence to a worrisome global problem (Rosa et al., 1992).

Worldwide, the problem of children roaming the street endlessly is escalating and alarming (Le Roux, 1996; Le Roux \& Smith, 1998). Global estimates of street children stood between 10-100 millions and the number was increasing rapidly since 2002 (UNFPA, 2003). This phenomenon has received such fame that it not only attracted national and international organizations but also governments are taking it on priority basis (Panter-Brick, 2002). Particularly in Sub-content the street children problem is relatively prevailing more as compared to other Contents (Iqbal 2008; Bruns et al., 2003). Nonetheless, recently, Sub-content is experiencing high urban growth rates (Burns et al., 2003). Urbanization in this particular region is rapidly growing; growth of population is also on the same graph, despite the features of wars, facing terrorism, internal economic crises and unequal distribution of wealth. Moreover, it is important to discuss that, increasing number of street children today partly reflect the extreme poverty and has resulted in lack of social services where the demands of highly populated urban are ever increasing. While, Pakistan is among the largest Muslim countries of the world with more than 180 million people has no exception from this scourge. Street children are featured problem of Pakistan, because thousands of street children are found in major urban areas. Commons abuses of Pakistani street children are also similar to rest the world that range from begging to vend and from robbery to prostitution. Most of the children work for the entire day to support their families. Due to fragility of their families, these children eventually find permanent places to lead their lives in streets. Moreover, numerous street children actually remain on the street and have little understandings of family environments. Relations may exist but practised occasionally or casually (Ali \& Muynck, 2005). This is also a fact that larger societies comprise homes and families, for the reason these families may be poor socially, economically, politically or combination of these (Tufail, 2005). That can ultimately be disturbing for the large economies and societies. In addition, in Pakistan there are two main types of street children found in major urban areas of Pakistan: first type is termed as children of street, those who work and live in streets; the second may be called children in street, those who return to their homes every night after working in streets full or part-time basis (UNICEF, 2008).

Street Children and Educational Attainment: Education can be defined as an act or process of cultivating and developing someone morally, physically or mentally, forming and regulating the principles and characters in order to enable them for becoming fit for business through systematic instruction (Dybicz, 2005). Moreover, Ebrahim (2004) refers education as "the aggregate of all the processes by which a child or 
adult develops the abilities, attitudes and other forms of behaviour which are of positive value to the society in which he lives, that is to say, it is a process of disseminating knowledge either to ensure social control or to guarantee rational direction of the society or both.". Street children are growing steadily in Pakistan since last two decades. In Pakistan, according to one estimate, mostly in town, 1.4 million children lead their lives without families as 'Street Children' (Ali et al., 2004; Wikipedia, 2014). Although, the aforesaid estimates needed to be realistically low but Pakistan is a country that has experienced unprecedented level of crisis ranging from such natural disasters resulting from drought to ethno-religious wars, wars of attrition and severe terrorism. All together these factors have added a significant leap in the number of Street Children in Pakistan recently estimated to be in the range of 1.3 to 1.7 million (Wikipedia, 2014). Initially, the majority of primary and secondary educational institutions were established and run by foreigner. A relatively few were Government-owned, Education is very important for sustaining and developing the people. With education, people are able to endure, mature. Acquire experience, wisdom and the capability to fend for themselves as well as serve their communities and nation. Education is also both an instrument of stability and of change: stability in the sense that good traditions are documented, taught, imbibed and practised, and changes because it equips people to meet new challenges. In the same vein education is a tool for inculcating moral values in the citizen (Tufail, 2005).

As a remedy, street educators teaching may be encouraged to help the street children. Street education comprises helping the children to acquire knowledge, attitudes and specific skills needed for their betterment. For this purpose, one should have to realize the necessities of street children and their specific local situations before going for any teaching, because teaching the street children about the issues which are not related to them is entirely waste of resources. Furthermore, family relationships play a vital role in developing pathway for their children (Hardee \& Leahy, 2008). Cognitive and social learning and cognitive theories may help in explaining that how violent parent-child relationships are shaped by the wider societies and communities. As social learning theory claims that virtually all learning occurs indirectly by observing the behaviours of other people and evaluating the outcomes whether desirable or not (Ebigbo, 2003). According to this theory, children suffer from various abuses because their parents have learned harsh childmanagement practices from the communities and societies because they also have faced these abuses in their childhoods. When the issue of Pakistan educational system are raised today, the first sets of thoughts that comes to mind are: deterioration of facilities, decline in standard, examination malpractices, mass promotion syndrome and the like before any other thing else (Emmanuel et al., 2009). This makes louder calls for more empirical studies aiming at tutoring each and every participant in the education system that how their actions and inactions can/have contributed individually and collectively in collapsing state of education.

According to the World Bank (1999: 25), "successful development entails more than investing in physical capital, or closing the gap in capital. It also entails acquiring and using knowledge as well as closing the gaps in knowledge". It is important for a developing country to confront the challenges of development successfully, by undertaking three major tasks: acquiring and adapting global knowledge and creating knowledge at local level. They should invest in human capital to increase the ability to use and absorb knowledge. Moreover, investment in technologies is important to facilitate both absorption and acquisition of knowledge. The precious roles and contributions of education in the development of an individual and the society cannot be over emphasized. Many developed and developing countries use education as a tool for promotion of national development along with acquiring the effecting desirable social change (NPE, 2004). Therefore it is the urgent need of the country to shape the future of this nation education to meet challenges ahead to achieve the relevance and quality gradually in the entire system of street children. In addition, relevance of education not seems to be much relevant to the current needs of the country these days. As per UNICEF (2009) many educators have expressed their concerns about the lack of relevance in their educational system in meeting the pressing cultural, economic and social needs of their nationals by providing education for the street children at the grass root level.

Street children issue also tends to be confronted as a universal issue like every other social issues and facts. The phenomenon street children arise as a result of these children being 'abandoned' by or themselves 'abandoning' their families and homesteads. Street Children has been growing steadily in the last two decades as children are been deprived of their right to education, the right to teach them effectively (Muhammad \& Zafar, 2006). Preventing and reducing the violence that children are forced to experience will eliminate 
significant factors pushing them onto the streets and negates the improvement in their quality of life, many marginalized groups are left uncared for and end up becoming a burden on NGOs. Among those who are not covered by most of these plans are street children; a group that constitute a major loss of human capital as they are potential criminals; people who, as a matter of fact live a life of dependency (Hyder, 2007). At this juncture, this study investigate the poor parental guidance forwarded to child which its aftermath effect leads to street activities which begging, hawking, and prostitution all this activities have been characterised as child abuse, as such there need for relative interventive measure.

\section{Methodology}

Research Design/ Method of Data Collection: The selection of respondents for this survey was based on EA map that was collected from National Population Commission, North-western State of Pakistan from which number of children on streets was selected. Of these children on the streets, a simple random sampling was used to select the children of the survey.

Sample Size Determinant: The prevalent rate of street children across the world is not universal but prevalent of 0.5 for the purpose this study and better sample size and since the target population is above 10000. At $95 \%$ confidence interval, the sample size is derived using the formula;

$$
\mathrm{N}=\left(\mathrm{P}\{1-\mathrm{P}\}\left(\mathrm{Z} \varpi^{2}\right) / \mathrm{d}^{2}\right.
$$

N-Sample size, P- Prevalence rate

Z- Normal distribution, df- Degree of freedom

$\mathrm{P}=0.5, \mathrm{q}=0.5$

$\mathrm{Z}_{\rrbracket^{2}}{ }^{2}=1.96^{2}$

$\left.\mathrm{N}=\left[0.5(1-0.5)\left(1.96^{2}\right) / 0.05^{2}\right)\right]$

$\{0.5(0.5)(3.8416) / 0.0025\}$

$\mathrm{N}=216.82$

The figure was approximated to 250 for the purpose of effective coverage.

Table 1: percentage distribution of background characteristics of street children

\begin{tabular}{lll}
\hline Characteristics & Frequency & Percentage \\
\hline Sex & & \\
Male & 115 & 46 \\
Female & 135 & 54 \\
Age & & \\
$2-5$ & 118 & 47 \\
$6-10$ & 60 & 24 \\
$11-15$ & 27 & 27 \\
$15-17$ & 45 & 18 \\
Education Status & & \\
None & 33 & 13.2 \\
Primary education & 90 & 36 \\
Secondary Education & 114 & 46 \\
Post-secondary Education & 13 & 5.2 \\
Religion & & \\
Muslims & 165 & 66 \\
Christianity & 72 & 29 \\
Other & 13 & 5.2 \\
Is parent currently working & & \\
Yes & 153 & 61.2 \\
No & 93 & 39 \\
Parental Occupation & & \\
Farming & 68 & 27.2 \\
Trading & 104 & 41.6 \\
Civil Servant & 21 & 8.4 \\
Artisans & 57 & 22.8 \\
\hline
\end{tabular}


Sources: 2013 Survey

Research Instrument: The questionnaire was structurally designed and worded in a simple and straightforward manner. To collect acute but adequate information necessary for the purpose of this study open as well as close ended questions were asked. To simplify the procedure of administration, the questionnaire was classified into sections. Section A of the questionnaire addressed information with respect to age, marital status, level of education and religion. Also contained questions on the socio-economic characteristics of the respondents with respect to their income of parent, occupation, and number of children

The other Section of questionnaire dealt with information relating to daily activities of street children, street hawking, and street begging.

\section{Results}

From the above information it reveals that, 54\% of the respondents were female while $46 \%$ were male, $47 \%$ of the respondent were within the age range of 2-5 years, while respondent within the age range of 6-10, 11$15,15-17$ years had 24, 27, 18 percent respectively, the study reveals that most respondents had secondary education this is represent by $46 \%, 66 \%$ of the respondent were Muslims while, Christian and other religion were $29 \%$ and $5.2 \%$ respectively, over $61 \%$ of the respondent had a parent currently, also in the same vein, over $41 \%$ of the respondent practice trading as an occupation, while $27.2 \%$ were respondent having $27.2 \%$ as faming, $8.4 \%$ were for civil servant, while $22.8 \%$ were for artisans.

\section{Table 2: Percentage of Problem Encountered on the Street}

\begin{tabular}{lll}
\hline Issues & Frequency & Percentage \\
\hline Causes of street activities & 36 & 14 \\
Death of parent/s or no caregiver & 56 & 22 \\
Parents living separately & 102 & 41 \\
Poverty & 17 & 7 \\
Ill-treatment from Home & 39 & 16 \\
Illiteracy/Truancy & & \\
Classification of jobs & 86 & 34 \\
Jobs with no moral condemnation & 77 & 31 \\
Jobs with moral condemnation & 87 & 35 \\
Jobs with moral/ without moral condemnation & & \\
Family contact & 115 & 46 \\
Frequent & 135 & 54 \\
Rare Never & & \\
Family Situation & 85 & 34 \\
Parent/s had/are stayed in your area & 102 & 41 \\
Parents never stayed in area & 63 & 25 \\
Don't know parent/s whereabouts & & \\
\hline
\end{tabular}

Based on the above information, it however reveals that, $41 \%$ of the respondents engage in street activities all because of poverty, also 35\% of the respondent engage in jobs with moral/without condemnation, also $54 \%$ of the respondents rare never sees their family members, parent never atayed in area such children can do stay in the area this supported with $41 \%$ percentage)

Table 3: Percentage of Abuse Experienced by Street Children

\begin{tabular}{lll}
\hline Forms of Abuse & Frequency & Percentage \\
\hline Health related issue & 95 & 38 \\
Problem with police & 81 & 32 \\
Big Boys (Alayes') & 15 & 6 \\
Accommodation & 29 & 12 \\
Feeding & 14 & 6 \\
Ritual makers & 16 & 6 \\
\hline
\end{tabular}


From the above table, it shows that street children experience various forms of abuse, health related issue represents 95(38\%), Problems with police 81(32\%), Big boys "Alayes" represents 15(6\%), accommodation $29(12 \%)$ also, feeding $14(6 \%)$, it was also discovered that street children experience abuse from ritual makers representing 16(6\%). To this end, street children are prone to health related issues.

\section{Table 4: Percentage of Surviving Strategies of Street Children}

\begin{tabular}{lll}
\hline Surviving Strategies & Frequency & Percentage \\
\hline Money Making Activities & 55 & 22 \\
Hawking & 102 & 41 \\
Haulage/Pushing cart/Carrying loads & 50 & 20 \\
Bus conducting & 17 & 7 \\
Selling stuff at a particular spot & 26 & 10 \\
Beg for Alms & & \\
Daily proceeds usage & 126 & 50 \\
Feeding and general upkeep of self & 24 & 9.6 \\
Keeping money with individuals in the garage & 100 & 40 \\
Carrying it wherever one goes & 87 & 35 \\
How belongings were kept & 30 & 12 \\
Inside dilapidated building & 108 & 43 \\
Inside vehicles & 25 & 10 \\
With shop owners & 21 & 8 \\
Putting on more than one clothing Items & & \\
Sleeping places & 88 & 35 \\
Inside dilapidated/abandoned building & 38 & 15 \\
Inside vehicle & 103 & 41 \\
Shops & & \\
\hline
\end{tabular}

Based on the above information, it shows the surviving strategies of street children, $41 \%$ of the respondent make money through Haulage/Pushing cart/Carrying loads, while other respondent make through various strategies which hawking, bus conducting, being for arms, in the same vein, 50\% engage in feeding and general upkeep of self „, also $43 \%$ keep their belongings with shop owners, $41 \%$ of the respondent sleep inside shop while others sleep inside dilapidated/abandoned building, and some sleep inside vehicles.

\section{Conclusion and Recommendation}

The UN Policy on education is that it is a human right (UN, 1948) and that all children must receive basic primary education, but the case of street children in North-western state of Pakistan have been characterized with various forms of violence and disgusting health issues. Overall the policies and interventions in place to deal with street children in Pakistan are both qualitatively and quantitatively inadequate; they are incapable of measuring, let alone managing, the street child phenomenon. The current political climate in Pakistan makes it difficult to imagine prioritization of street children in the foreseeable future, however the way forward entails learning lessons from examples of successful interventions internationally. The study reveals problem encountered on the street by the children, also their surviving strategies which varies, abuse experienced by street children as also called for urgent attention by Community Based Organisations, Policy makers, social welfare institutions in Pakistan, to take-up to the challenge of improving on welfare of children on the street. The study however recommends that there is a need to strengthen education system. There are some children who have been criminally active while on the street. Such children need counselling and thorough consistent education, Assisting in the vocational Training, Improvement of the curriculum, all these tends to improve on psychosocio level of street children even in a superlative approach

\section{References}

Ali, M., Shahab, S., Ushijima, H. \& Muynck, A. D. (2004). Street Children in Pakistan: A situational Analysis of Social conditions and Nutritional status. Social Science \& Medicine, 59(1), 1707-1717. 
Ali, M. \& Muynck, A. D. (2005). Illness incidence and health seeking behavior among street children in Rawalpindi and Islamabad, Pakistan - a qualitative study. Child: Care, Health and Development, 31(5), 525-532.

Asian Human Rights Commission. (2005). Pakistan: Number of street children on the rise. Available: http://acr.hrschool.org/mainfile.php/0236/483/. Last accessed 25 March 2009.

Bruns, B., Minat, A. \& Rakotomalala, L. (2003). Achieving the Universal Primary Education by 2015. A chance for Every Child. Washington, World Bank Basic Education. Biannual Conference Tanzania

Central Intelligence Agency (CIA). (2009). Pakistan: Country Map and Profile. Available: https://www.cia.gov/library/publications/the-world-factbook/geos/pk.html. Last accessed 09 April 2009.

Development Bank, TA No. 3043 INO. Cited in Pinheiro, P. (2007). World Report on Violence against Children.

Dybicz, P. (2005). Interventions for street children: An analysis of current best practices. International Social Work, 48(6), 763-771.

Ebigbo, P. O. (2003). Street Children: The Core of Child Abuse and Neglect in Nigeria, Children, Youth and Environment 13(1), spring Retrieved from http://cye.colorudo.edu.

Ebrahim, Z. (2004). Pakistan: Programme seeks to Ease Harsh Street Life, Drug Use. Available: http://www.aegis.org/news/ips/2004/IP040202.html. Last accessed 25 March 2009.

Ekundayo, J. D. (2001). Successful Experiences in Nonformal Education and Alternatives approaches to

Emmanuel, F., Archibald, C., Razaque, A. \& Sandstrom, P. (2009). Factors Associated With an Explosive HIV Epidemic Among Injecting Drug Users in Sargodha, Pakistan. Journal of Acquired Immune Deficiency Syndrome, 00(0), 22-28.

Hardee, K. \& Leahy, E. (2008). Population, fertility and family planning in Pakistan: A program in stagnation. Population Action International, 3(3).

Hyder, A. A. (2007). Violence against children: a challenge for public health in Pakistan. Journal of Health Population and Nutrition, 25(2), 168-178.

Iqbal, S. (2008). Street Children: An Overlooked Issue in Pakistan. Child Abuse Review, 17(1), 201-209.

Jung Newspaper. (2012). http://e.jang.com.pk/03-11-2012/Lahore/page6.asp

Le Roux, J. (1996). Street children in South Africa: findings from interviews on the background of street children in Pretoria, South Africa. Adolescence, 31(122), 423-431.

Le Roux, J. \& Smith, C. S. (1998). Causes and characteristics of the street child phenomenon: a global perspective. Adolescence, 33(131), 683-688.

Muhammad, T., Zafar, N. (2006). Situational Analysis Report on Prostitution of Boys in Pakistan (Lahore \& Peshawar). Pakistan Paediatrics Association.

Panter-Brick, C. (2002). Street Children, Human Rights, and Public Health: A Critique and Future Directions. Annual Review of Anthropology, 31, 147-171.

Rosa, C. S. A., Borba, R. D. S. \& Ebrahim, G. J. (1992). The Street Children of Recife: a Study of their Background. Journal of Tropical Paediatrics, 38(1), 34-40.

Tufail, P. (2005). Situational Analysis of Street Children Education for All Policy Review and Best Practices Studies on Basic NFE for Children Living and/or Working on the Streets in Pakistan. AMAL Human Development Report.

United Nations Children's Emergency Fund (UNICEF). (2008). The State of the World's Children. Available: http://www.unicef.org/sowc09/. Last accessed 12 December 2008.

United Nations Office on Drugs and Crime (UNODC). (2004). Solvent Abuse among Street Children in Pakistan. The United Nations System in Pakistan. 19-39.

Wikipedia (2014). http://en.wikipedia.org/wiki/Street_children. 